\title{
Turistlerin Tatil Dönemlerinde Sergiledikleri Liminoid Davranışlar ${ }^{1}$
}

Semra AKTAŞ POLAT, Department of Tourism Management, Faculty of Management, Sakarya University, Turkey, e-mail: saktas@sakarya.edu.tr

\section{Liminoid Behaviors of Tourists on Vacation Periods ${ }^{2}$}

\begin{abstract}
The purpose of this study is to identify the liminoid behaviors exhibited on vacation periods by tourists and to discover whether there is a statistically significant difference between liminoid behaviors and nationality and types of tourism. According to the results of the analyses, it is discovered that there is a statistically significant difference between the liminoid behaviors and participants' nationalities, and there is also a statistically significant difference between the liminoid behaviors and the types of tourism in which the participants involved. As a result of this research, the five types of liminoid behaviors (hedonism, privacy, tolerance-anomaly, identity detachment, play-player) related to vacation periods have been identified. According to this classification, five types of tourists are suggested; hedonist, anonymous, permissive, faceless and player under "liminoid tourist" concept.
\end{abstract}

Keywords Tourist Psychology, Liminoid, Tourist Behavior, Tourism.

JEL Classification Codes $\quad$ : M100, M310, M390.

\section{$\ddot{\mathbf{O} z}$}

Bu çalışmanın amacı, tatil dönemlerinde sergilenen liminoid davranışların belirlenmesi ve söz konusu davranışlar ile milliyet ve tatil türü arasında anlamlı bir farklılık olup olmadığının tespit edilmesidir. Analiz sonuçlarına göre, tatil dönemlerinde sergilenen liminoid davranışlar ile katılımcıların milliyeti ve katılımcıların tercih ettiği tatil türü arasında istatistiksel açıdan anlamlı bir farklılık olduğu tespit edilmiştir. Bu araştırmanın sonucunda, tatil dönemine ilişkin beş tür (hazcılık, gizlilik, tolerans-kuralsızlık, kimliğinden sıyrılma, oyunoyuncu) liminoid davranış tespit edilmiştir. Bu davranış türlerinden hareketle; hazcı, gizli, hoşgörülü, kimliksiz ve oyuncu olmak üzere "liminoid turist" kapsamında beş turist türü önerilmiştir.

Anahtar Sözcükler $\quad$ : Turist Psikolojisi, Liminoid, Turist Davranışı, Turizm.

I Bu çalışma Prof.Dr. Orhan BATMAN'ın danışmanlığında, Semra AKTAŞ POLAT'ın 2013 yılında tamamlanan "Turistlerin Tatil Dönemlerinde Sergiledikleri Geçici Davranış Değiş̧iklikleri (Liminoid) Üzerine Bir Araşstırma" başlıklı doktora tez çalışmasından üretilmiştir. Ayrıca bu çalışma 2011-60-02-003 proje numarası ile Sakarya Üniversitesi Bilimsel Araştırma Projeleri Komisyonu Başkanlığı tarafindan desteklenmiştir.

2 This study was derived from Semra Aktas Polat's dissertation titled as "A Research on Liminoid Behaviors of Tourists on Vacation Periods" which was completed in 2013 and supervised by Prof.Dr. Orhan Batman and was also supported with the code 2011-60-02-003 by Sakarya University Scientific Research Projects Commission. 


\section{Giriş}

Tatil dönemi ve turist davranışını psikolojik bir yaklaşımla ele alan bu çalışma, bireyin turist olduğu dönemde günlük yaşamından daha farklı bir kimliğe büründüğünü savunur. Daha açık bir ifade ile tatil dönemi, günlük yaşamın hayali bir eşik ile ayrılarak insanların tatilde geçirdikleri bir dönem olarak kabul edilebilir.

İnsan, tatil dönemlerinde isteyerek ya da bulunduğu ortama ayak uydurmak için günlük rutinlerini, hatta sınırlarını aşarak bazı değerlerini askıya almaktadır. İnsan, bahsedilen sınırları aşma durumunda birkaç günlüğüne de olsa "kendisi olmaya" ara vererek, tatilde farklı bir şekilde kendisini yaşamaktadır. Söz konusu eşik sürecinde, tatildeki ve günlük yaşamdaki kişiler aynı kişiler olmasına rağmen, bu kişilerin hal ve davranışları farklı olabilmektedir. İnsanların farklı davranışlar sergilemesinin nedeni olarak, turist olmanın özündeki zevk ve eğlence faktörü belirtilebilir.

Çalışmanın temel amacı, turist davranışı ve turist psikolojisini anlamlandırmada "liminoid" kavramını kullanarak, turizm literatürene farklı bir bakış açısı kazandırmaktır. $\mathrm{Bu}$ temel amaç kapsamında yapılan araştırma, turistlerin tatil dönemlerinde sergiledikleri liminoid davranışların neler olduğunun belirlenmesi üzerine kurgulanmıştır. Bu çalışmada, liminoid olarak bahsedilen davranışlar; özünde "eğlence ve hazzı” barındıran günlük yaşam davranışları ile çoğu zaman farklı bir düzeyde gerçekleştirilen, oyuncu ve gayri ciddi özellikleri olan davranışları içermektedir.

Araştırma konusu dâhilinde; Turist kimdir? Turist olmak nasıl bir duygudur? ve turist tatilde ne yapar? gibi bir takım sorulara da cevap aranmaktadır. Turistlerin temel hedefi eğlenmek, dinlenmek ve gündelik yaşamda yaşayamadıklarını tatil dönemlerinde yaşamaktır. Turistlerin bu isteği işletmecileri, insanlara farklı deneyimler yaşatacak tarzda ürünler üretmeye sevk etmekte ve turistlerin maksimum tatmin duyabileceği ortamlar için zemin oluşturmaktadır.

Bu çalışmada, standart davranış normlarının terk edildiği tatil dönemi "liminoid dönem" olarak adlandırılmaktadır. Liminoid dönemde, zaman farklı bir şekilde yaşanıyor, alışılmışlıklar yerini bilinmeyene bırakıyor ve sıradan olan yaşam yerini sıradışılığa bırakıyor. Liminoid davranış için önemli olan, insanların tatil dönemlerinde günlük yaşamlarından farklı bir psikoloji ile hareket etmeleridir. Daha açık bir ifadeyle, insanların turist psikolojisiyle hareket edip, günlük yaşamlarındaki kaygılarını unutarak ya da unutma isteğiyle, tamamen tatile odaklanmış olarak anı yaşamalarıdır. Liminoid davranışların temel özelliği, geçici olması ve kısa süreliğine görülmesidir. Liminoid davranışlar, birey liminoid evreden ayrıldığında yavaşça kaybolmakta ve kişi artık bir uyanıklık haline geçmektedir. 


\section{Liminoid ve Turizm}

Geçiş ritüelleri insanın bir statüden diğer bir statüye geçtiği, toplum tarafından organize edilen geleneksel ritüellerdir (van Gennep, 1909: 10; Honko, 2006: 131). Van Gennep (1909: 10) geçiş ritüellerini ayrılma (seperation), geçiş-eşiksellik/liminal (transition) ve bütünleşme (incorporation) evresi olmak üzere üç aşamada incelemiştir. Ayrılma (seperation) belirgin olarak cenaze törenlerinde, bütünleşme düğün törenlerinde ve geçiş ritüelleri ise gebelik, nişanlılık, erginlenme ya da ikinci bir çocuk, ikinci bir evlilik veya orta yaş grubundan üçüncü yaş grubuna geçiş gibi insan hayatında önemli rol oynayabilecek dönemleri içerir (van Gennep, 1909: 11). Turner (1974: 232) bu üç aşamay1 şu şekilde özetlemiştir;

- $\quad$ Ayrılma evresi; bireyin ya da grubun önceki statüden ayrılışını simgeleyen ayrılma/kopuş evresidir.

- $\quad$ Liminal evre; kişinin eski statüden ayrılmakla birlikte henüz yeni statüye de varamadığı, ne eski ne de yeni statüsüyle ilişkisinin olmadığı geçiş/eşiksellik evresidir.

- Bütünleşme evresi; bir statüden diğerine geçişin sembolik olarak tamamlandığı yeniden bütünleşme evresidir.

Bu çalışmada, üzerinde önemle durulan konu geçiş ritüellerinin ikinci evresi olan liminal evredir. Liminal (geçiş-eşiksellik) dönemde, bireylerin geçmiş ve gelecek konumları göz ardı edilmekte hatta tersine çevrilmektedir. Liminality, sıradan yaşamın (sosyal statülerin-fakirin zengin olması, zenginin fakir olması, kralların ve soyluların yer değiştirmesi) tersine dönmesi olarak düşünülebilir (Turner, 1979: 467; Kottak, 1991: 242243).

Turner (1979) liminal kavramının karşısına liminoid kavramını yerleştirmiştir. Turner'ın (1979: 492-496) ifadesine göre liminal; ilkel ve erken tarım topluluklarında, liminoid ise merkezden uzakta, ekonomik ve politik süreçlerin dışında hizmet endüstrisinde görülmektedir. Turner (1979) esasında liminoidi, karnavallardaki, festivallerdeki ve geçiş törenlerindeki garip ve farklı davranışlar olarak yorumlamıştır. Horn (2010: 95) liminoid faaliyetlerin zorunlu olmadığını, isteğe bağlı olduğuna ve bireye yapı içinde esnek bir şekilde kendisini ifade etme olanağı sağladığına değinmiştir. Liminoid kavramı, endüstri toplumlarının dinle ilgili olmayan çerçevesinde oluşan, sıra dışı faaliyetleri içermektedir (Korg, 1995: 9; Illouz, 1997: 142).

$\mathrm{Bu}$ söylemler 1şığında, çalışmanın alanına giren turizm etkinliklerinin gerçekleştirildiği ortamın liminoid karakterde olduğu söylenebilir. İlgili literatürde liminoid 
kavramını turizm ile ilişkilendiren çalışmalara (Lett, 1983; Currie, 1997; Ryan, 2002; Selanniemi, 2003; Galani-Moutafi, 2003; Shaw \& Williams, 2004; Pearce, 2005; Getz, 2008; Bauer, 2009; Varley, 2011; Berdychevsk vd., 2013) rastlanılmaktadır.

Söz konusu liminoid durumlar, günlük rutinlerin geçici olarak askıya alındığ veya tersine döndürüldüğü durumlar olarak açıklanmıştır (Wagner, 1977). Egan (2009: 42) liminoid aktivitelerin, tersine dönme ritüeli (rite of reversal) ile ifade edilebileceğini belirtmiş ve bu ifadesini turistleri örnek vererek açıklamıştır. Turizm alanından örnekler incelendiğinde bu çalışmaların bazılarında ilgili konunun "reversal theory-rollerin ve/veya statülerin tersine çevrilmesi teorisi” kapsamında ele alındığı görülmüştür. Örneğin Williams (1998: 9) turizmde norm ve kurallara aykırı olan davranışlardaki değişimin geçici olduğunu ifade etmektedir. Getz (2008: 414) liminoid kavramının, kimliğin ve sosyal statünün kaybını ve rollerin tersine çevrilmesini ifade ettiğini belirterek, liminoidin festivaller ile şenlikler için geçerli olabileceğini ifade etmiştir. Shaw ve Wlliams (2004: 151) bazı bireylerin tatilde olduklarında, alışılmış davranışlarını terk ettiklerinden ve tatil sırasında bu özel durumla ilgili ruh halini ifade eden oyun kavramının liminoid olarak kavramsallaştırıldığından bahsetmişlerdir.

Lett'in (1983: 36) ifadesine göre, çoğu toplumda, özel durumlarda alışılmış kurallar ve günlük yaşam kuralları bir kenara atılır, askıya alınır ve geçici olarak ters yüz edilir. Ludic (oyuncul) ve liminoid durum turistlere yapı karşıtı davranma hakkını verir. Gottlieb (1982: 168) tatilin ideal tanımını, tersine dönme (inversion) kavramı çerçevesinde tanımlamış ve bu kavramı, günlük hayatta yapılanların tersinin yapılması şeklinde ifade etmiştir. Currie (1997: 885) ise turist davranışlarının genellikle günlük yaşamdan farklı olduğunu ifade etmiştir.

Literatür bulgularından hareketle turizm etkinliklerinin liminoid bir karekterde olduğu, turizm etkinlikleri esnasında geçici olarak turistlerin rollerini, statülerini ve alışkanlıklarını tersine çevirerek oyun ve eğlence içerikli "liminoid davranışları" sergiledikleri ifade edilebilir. Konuya seyahat motivasyonlarından birisi olarak görülen "kaçış" (Dann, 1977; Dann, 1981; Swarbrooke \& Horner, 1999) güdüsü açısından yaklaşan çalışmalara da rastlanılmaktadır. Örneğin Ryan’a (2002: 4) göre turizm etkinliklerine katılım evden, sosyal sorumluluklardan ve zorunluluklardan bir kaçıştır. Benzer bir şekilde Sommer (2005: 2) turizmin mantıktan ve stresli yaşamdan geçici bir kaçış olarak kabul edildiğini ifade etmiş ve liminoid dönemde, turistik destinasyonda bir turist olarak zaman harcayanların; ciddi olmayan ve günlük yaşamda kınansa bile turizm alanında hoş karşılanan, oyuncul davranışlar sergilediklerini belirtmiştir. Son olarak Pearce (2005: 2526) turist rolünün sık sık anılan sonuçlarından birinin kültür şoku olduğunu vurgulamıştır. Pearce'a (2005) göre kültür şoku liminoid bir bölgeye girilmesinin bir sonucudur. 
Bu çerçeveden bakıldığında, özellikle prestij/benlik geliştirme, sorumluluklardan uzaklaşmak/kaçmak, saygınlık, özgürlük ve eğlenmek gibi insanları seyahate yönlendiren seyahat motivasyonlarının ardında araştırmanın inceleme konusu olarak seçilen liminoid olgusunun olduğu ifade edilebilir. Bu çalışmada, kişilerde tatil dönemlerinde görülen geçici davranış değişiklikleri liminoid ifadesiyle karşılanmış ve günlük yaşamdan farklı olarak sergilenen eğlence ve haz odaklı davranışlar tatil dönemlerinde sergilenen liminoid davranışlar olarak ele alınmıştır.

\section{Araștırmanın Amacı ve Önemi}

$\mathrm{Bu}$ çalışmanın temel amacı, turist davranışı ve turist psikolojisini anlamlandırmada "liminoid" kavramını kullanarak turizm literatürüne farklı bir bakış açısı kazandırmaktır. Bu temel amaç kapsamında yapılan araştırma, turistlerin tatil dönemlerinde sergiledikleri liminoid davranışların neler olduğunun belirlenmesi üzerine kurgulanmıştır. Tatil döneminde sergilenen eğlence ve haz odaklı liminoid davranışlara ilişkin boyutların belirlenmesi ve bu liminoid davranışların turistlerin katıldığı tatil türü ve milliyete göre farklılık gösterip göstermediğinin tespit edilmesi amaçlanmaktadır.

Bu araştırmayı özgün ve önemli kılan özelliği kuramsal açıdan turizme "liminoid davranış" kavramını kazandırmış olmasıdır. Çalışmanın turisti psikolojik açıdan ele alması yönüyle de turist ve turizme farklı bir açıdan bakılmasını sağlayacağı düşünülmektedir. Bu yönüyle turizm literatürüne önemli bir katkı sağlayarak, bu konuda kaynak zenginliği sağlayacaktır. Böylece bu çalışmanın turist davranışı üzerinde çalışan ve çalışmak isteyen araştırmacılar için temel bir kaynak olabileceği düşünülmektedir.

\section{Yöntem}

Literatür taraması sonucu elde edilen ikincil verilerin yanında, seyahat öncesi, seyahat dönemi ve seyahat sonrası deneyimlerin tespit edilebilmesi için araştırmacı, tatil yapan turistleri gözlemlemek amacıyla bir tur programına katılmıştır. Araştırmacı, gözlemlenen durumun içerisinde bir katılımcı olarak yer almıştır. Seyahat öncesinde kişilerle yapılan görüşme sonuçları, tatil esnasında turistlerle yapılan görüşmeler ve katılımcı gözleme dayanan sonuçlar ile tatil sonrası yapılan görüşmelerin ardından mülakat raporlarının değerlendirilmesi sonucu bir anket formu oluşturulmuştur. Anket formu yardımıyla kişilere uygulanacak olan anket çalışmasından elde edilen veriler nicel yöntemlerle analiz edilmiştir.

Turistin tatilini geçirdiği yerde sergilediği davranışlar ile günlük yaşamını sürdürdüğü yerde sergilediği davranışlar arasında farklılıklar olduğu temel varsayımından 
hareketle, bu araştırmanın problemini turistin günlük yaşamını sürdürdüğü yerde sergilediği davranışlardan farklı olarak, tatil döneminde sergilediği liminoid davranışların belirlenmesi olarak ifade edebiliriz. Araştırmanın temel probleminin dışında tatil dönemlerinde sergilenen liminoid davranışlar ile turistin milliyeti ve katıldığı tatil türü arasında bir farklılığın olup olmadığı irdelenmektedir. Araştırmada yapılan literatür taramasından hareketle görüşme tekniğinin kullanılması öngörülmüş fakat pilot uygulama esnasında araştırmanın doğası gereği turistin özel yaşamına ilişkin bir takım düşünceleri sorgulaması açısından katılımcıların bu tarz ifadelere yanıt vermekten kaçındıkları görülmüştür. $\mathrm{Bu}$ nedenle yapılan yarı biçimlendirilmiş görüşmelerden sonra, araştırmada anket tekniğinin uygulanması uygun görülmüştür. İlgili literatürün taranması, yapılan yarı biçimlendirilmiş görüşmeler ve uzman görüşleri yardımıyla bir anket formu hazırlanmıştır. Böylece katılımcının, araştırmacı ile yüzyüze olmadığından ve kimlik bilgileri de istenmediğinden soruları daha rahat bir şekilde yanıtlayabileceği varsayılmıştır. Bu araştırma, Türkiye'de kitle turizmi bölgeleri olan Antalya ve Muğla ile kültür turizm bölgesi olan İstanbul'da 2012 yılında Haziran-Temmuz-Ağustos aylarında tatilini geçiren sınırlı sayıda Alman, Rus, İngiliz, Arap ve Türk turistlerle sinırlıdır.

2012 yılı yaz döneminde, Antalya, Muğla ve İstanbul'a turist olarak gelen Alman, Arap, İngiliz, Rus ve yurt dışında ikamet eden ve tatilini geçirmek için gelen Türk vatandaşları bu araştırmanın evrenini oluşturmaktadır. 2012 ${ }^{3}$ yılında Türkiye'ye gelen Alman turist sayıs 5.028.745; Rus turist say1s1 3.599.925; İngiliz turist say1s1 2.456.519; Arap $^{4}$ turist sayısı 2.440.721 ve Türk turist sayısı (yurt dışında ikamet eden Türk Vatandaşlar dâhil) 11.731.463'tür (Kültür ve Turizm Bakanlığı, 2013; Türkiye İstatistik Kurumu, 2013). Toplamda ise 25.257.382 kişi bu araştırmanın evrenini oluşturmaktadır. Böyle bir çalışmada evren büyüklüğü için Sekaran (1992: 253'den akt. Altunışık vd., 2012: 137) ölçeğine göre 384 örneklem sayısının yeterli olacağı ifade edilebilir. Örnekleme ulaşmada olasılığa dayalı olmayan örnekleme yöntemlerinden ankete cevap veren herkesin örneğe dahil edilmesi (Altunışık vd., 2012: 142) şeklinde tanımlanan kolayda örnekleme tekniği kullanılmıştır.

3 Araştırma 2012 yılı Haziran- Temmuz- Ağustos aylarında gerçekleştirilmiş olduğundan güncel verilere metin içinde yer verilmemiştir.

4 Arap turist sayısına ulaşmak için; Misır, Sudan, Fas, Cezayir, Suudi Arabistan, Irak, Yemen, Suriye, Tunus, Somali, Ürdün, Libya, Filistin, Lübnan, Moritanya, Umman, Birleşik Arap Emirlikleri, Kuveyt, Katar, Bahreyn, Komor ve Cibuti'den gelen vatandaş sayllarından yararlanılmıştır. 


\section{Soru Formunun Oluşturulması ve Uygulanan Testler}

Araştırmada, öncelikle tatil dönemlerinde turistlerin sergilediği liminoid davranışlar ile ilgili literatür taraması yapılmıştır. Literatürden elde edilen veriler ışığında; tatil yapmayı planlayan, tatilde olan ve tatilini tamamlamış toplam 40 kişi ile yarı biçimlendirilmiş görüşme gerçekleştirilmiştir.

Nitel araştırmaların geçerlilik ve güvenilirliği araştırmacının elde ettiği kayıtlarla veya yaptığı yorumlarla gerçek hayattaki kişinin, grubun veya kurumun gerçeklerinin örtüşme derecesine bağlıdır. Kayıtlar ve yorumlar gerçeğine uygun olduğu ölçüde geçerli sayılır ve sınamalarda aynı çıktığı ölçüde ise güvenilirdir (Şencan, 2005: 500). Bu bilgiden de yola çıkılarak, yapılan yarı biçimlendirilmiş mülakatlar her defasında rapor edilerek, yapılan görüşmelerde katılımcıların birleştikleri ve ayrıldıkları noktalar üzerinde durulmuştur.

Literatürden elde edilen verilere, görüşme sonuçları ve araştırmacı tarafından gerçekleştirilen katılımlı gözleme ilişkin değerlendirmeler de eklenerek uzman görüşlerine başvurulmuştur. Literatür verileri, katılımcı gözlem değerlendirmeleri, görüşme sonuçları ve uzman görüşlerinin sentezlenmesi sonucunda bir soru formu oluşturulmuştur.

Anket ölçeklerinin geliştirilmesinde madde havuzu oluşturma, uzman görüşleri, ön test, faktör analizi ve güvenilirlik basamakları takip edilir (Karasar, 1995: 139-143). İlgili yazın taraması ve yapılan pilot uygulamaların ardından hazırlanan soru formu ilk etapta 2012 Haziran-Temmuz ayları arasında uygulanmıştır. Ön test kapsamında, İstanbul, Antalya ve Muğla illerinde uygulanan anketlerden 76 adedi ele alınmıştır. Ön test için toplanan anketler araştırmanın evrenini oluşturan milliyetler bazında toplanmıştır. Pilot çalışma neticesinde, bazı ifadelerin soru formundan çıkarılmasına ve bazı sorularda anlam karışıklığına neden olan sözcüklerin daha yalın sözcüklerle değiştirilmesine karar verilmiştir.

Soru formunun güvenilirliği, içsel tutarlılık analizi yaklaşımına göre ölçülmeye çalışılmış ve bu analizde en yaygın kullanılan yöntem olan Cronbach Alpha olarak bilinen alfa katsayısına bakılmıştır. Düzenleme sonucunda yapılan güvenilirlik analizi sonucunda alfa (cronbach alpha) değeri 0.770 olarak tespit edilmiştir. . Kabul edilebilir bir değerin en az 0.7 olması arzu edilir(Altunışık vd., 2012: 126). Güvenilirlik analizi sonrasında tatil dönemlerinde sergilenen liminoid davranışlara ilişkin boyutlar belirlenmiştir. Soru formunda gerekli düzenlemeler yapılarak, soru formuna son hal verilmiş ve uygulamaya konmuştur. Belirlenen evren ve örneklem çerçevesinde toplanan 465 anket araştırmaya dâhil edilmiştir. 
$\mathrm{Bu}$ araştırmada yerli ve yabancı turist davranışlarını ve profilini belirlemede turistlerin milliyeti ve katıldıkları tatil türü temel değişkenler olarak kabul edilmiştir. Yazın taramasından hareketle yapılan bu çalışmada, turistlerin tatil dönemlerinde sergiledikleri liminoid davranışlar ile ilişskili olan faktörlere yönelik test edilecek olan hipotezler şunlardır:

Hipotez 1: Liminoid davranış sergilemede milliyete göre farklılık vardır.

Hipotez 2: Liminoid davranış sergilemede tatil türüne göre farklılık vardır.

Araştırmacıyı bu iki hipoteze yönelten temel neden literatür taraması sonucunda liminoide özgü davranışların en fazla görüldüğü alanlar olarak sahil kenarlarının örnek verildiği kanaatine varılmıştır. $\mathrm{Bu}$ nedenle, $\mathrm{H}_{2}$ olarak belirlenen liminoid davranış sergilemede tatil türüne göre farklılık vardır hipotezi teste konu edinilmiştir. Bununla birlikte, söz konusu davranışların milliyete göre bir farklılık gösterip göstermediği de $\mathrm{H}_{1}$ hipoteziyle sorgulanmıştır.

Katılımcıların milliyeti ile tatil dönemi sergilenen liminoid davranış ifadelerine yönelik olarak verilen yanıtlar arasında anlamlı bir farklılık olup olmadığı, Tek Yönlü Varyans Analizi ile test edilmiş ve istatistiksel açıdan anlamlı farklılık bulunan davranışların hangi milliyetten kaynaklandığını anlamak için ikili karşılaştırmalar (post-hoc), Tukey düzeltmesi kullanılarak yapılmıştır. Katılımcıların katıldıkları tatil türü ile liminoid davranış ifadelerine verdikleri yanıtlar arasında istatistiksel açıdan anlamlı bir farklılık olup olmadığı ise Bağımsız Gruplar Arası T Testi ile test edilmiştir. Gerçekleştirilen normallik sınaması sonucunda verilerin normal dağılıma sahip olduğu sonucuna varılmıştır. Bu nedenle verilerin analizinde parametrik testler kullanılmıştır.

\section{Verilerin Analizi ve Bulguların Yorumlanması}

Araştırmaya katılan 465 katılımcının cinsiyet, yaş ve medeni durumlarına göre dağılımı şu şekildedir; katılımcıların \%41.7'si kadın, \%56.8'i erkektir. \%21.3'ü 18-25 yaş, $\% 30.1$ 'i 26-35 yaş, \%25.4'ü 36-45 yaş, \%15.1'i 46-55 yaş ve \%4.52'si 56-65 yaş aralığındadır. Katılımcıların \%47.1'i evli ve \%42.4'ü ise bekârdır. Milliyete göre ise; Türk, Rus ve Arap katılımcıların her birinin oranı \%20, İngiliz katılımcıların oranı \%20.4 ve Alman katılımcıların oranı ise \%19.6'dır. 


\section{Turistlerin Tatil Dönemlerinde Sergiledikleri Liminoid Davranışlar}

Analizleri güçlendirmek ve söz konusu davranışların turistlerin milliyeti ile katıldıkları tatil türü arasındaki farklılıkları genel bir çerçevede inceleyebilmek için soru formu maddeleri üzerine faktör analizi uygulanmıştır. Yürütülen Temel Bileşenler Analizi'nde Kaiser Meyer Olkin (KMO) değeri 0.909 olarak elde edilmiştir. Katılımcıların verdiği cevaplara göre değişkenler arasındaki korelasyonun hesaplanarak, temel bileşenler tekniği ile varimax döndürmesine göre yapılan faktör analizi sonucunda, soru formunun yapısı değerlendirilmiş ve madde sayısı 45 'ten 23 'e indirilmiştir.

Faktörler üzerinde 0.40 yükleme değeri ölçüt alınarak 5 faktör bulunmuş ve analiz sonuçları Tablo 1'de verilmiştir. Alpha (Cronbach) değeri 0.904 olarak tespit edilmiştir. Toplam açıklanan varyans ise \% 55.187'dir. Birinci boyut "hazc1lık"; ikinci boyut "gizlilik"; üçüncü boyut "tolerans ve kuralsızlık"; dördüncü boyut "kimliğinden sıyrılma" ve beşinci boyut ise "oyun/oyuncu davranışı" olarak tanımlanmıştır. Boyutların isimlendirilmesinde literatürden yararlanılmış olup, elde edilen boyutların genel itibari ile literatürü desteklediği görülmektedir.

Tablo 1'e göre, toplam açıklanan varyans \%55.187'dir. Birinci boyut açıklanan varyansın \%32.974'ünü, ikinci boyut \%6.8'ini, üçüncü boyut \%5.765'ini, dördüncü boyut \%5.022'sini ve beşinci boyut \%4.627'sini açıklamaktadır. Bu sonuçlara göre bakıldığında, birinci boyutun değerinin, diğerlerine oranla oldukça yüksek olduğu görülmüştür. Söz konusu ifadelerin aslında tek boyutu temsil ettiği de ifade edilebilir. Bu davranışlar şu şekilde açıklanabilir;

“Hazcılık" davranışında; kişi tatil döneminde ne hissediyorsa, nasıl yaşamak istiyorsa öyle davranır. Bu davranış türünde; sınırsız eğlence, sorumlulukların terki, anı yaşama ve ilkel isteklerin tatminine yönelme ifadelerinin hepsi birlikte bireylerin, tatil anlarında hazcı deneyimlere odaklanmaya yönelik değerlendirmelerini içermektedir.

“Gizlilik" davranışında; turist, tatil döneminde tıpkı maskeli bir baloda olduğu gibi farklı bir kimlikle, kimsenin kendisini tanımadığı bir ortamda yaşamak istediği kimliğini yaşayacaktır. Bu davranış türünde turist, tatil yaptığı yeri günlük yaşamında yapamadıklarını yapabileceği gizli mekânı olarak görmektedir. Bu gizli kimlik, kişiye uygun olmadığını bildiği bazı şeyleri yaptıran bir kimliktir. Burada bahsedilen, kişinin gizli bir mekânda yaptıklarının gizli kalmasını istemesi ve sahip olduğu bir takım değer ve inançlarını sessizce terk etmesidir. 
Tablo: 1

Liminoid Davranış Soru Formu Faktör Analizi Sonuçları (n:465)

\begin{tabular}{|c|c|c|c|c|}
\hline Faktörler & $\begin{array}{l}\text { Faktör } \\
\text { Yükleri }\end{array}$ & $\begin{array}{c}\text { Varyans } \\
\text { Açıklama } \\
\text { Oranı }\end{array}$ & $\begin{array}{l}\text { Kümülatif } \\
\text { Varyans }\end{array}$ & $\begin{array}{c}\text { Güvenilirlik } \\
\text { Katsayısı }\end{array}$ \\
\hline Boyut 1: Hazcılık (Hedonizm) & & 32.974 & 32.974 & 0.793 \\
\hline $\begin{array}{l}\text { Tatilde, normal yaşantımda görüşmeyeceğimi bilsem de } \\
\text { tanımadığım insanlarla vakit geçirmek hoşuma gider. }\end{array}$ & .697 & & & \\
\hline $\begin{array}{l}\text { Tatillerde ne hissediyorsam, nasıl yaşamak istiyorsam öyle } \\
\text { davranırım. }\end{array}$ & .684 & & & \\
\hline Tatillerde günübirlik arkadaşlıklar kurarım. & .669 & & & \\
\hline Tatilde kısa bir anlık da olsa lüks yaşamı tatmak isterim. & .593 & & & \\
\hline $\begin{array}{l}\text { Tatilde eğlence mekânlarında normalden daha çok vakit } \\
\text { geçiriyorum. }\end{array}$ & .541 & & & \\
\hline Tatil dönemlerinde eğlenceyi sınırsızca yaşamaya çalışırım. & .502 & & & \\
\hline Boyut 2:Gizlilik & & 6.800 & 39.774 & 0.801 \\
\hline $\begin{array}{l}\text { Tatilde kendimi maskeli bir baloda gibi hissederim } \\
\text { (kimsenin beni tanımadığı bir ortamda tamamen farklı bir } \\
\text { kimlikte olurum) }\end{array}$ & .675 & & & \\
\hline $\begin{array}{l}\text { Tatilde yaptıklarımı ailemin (anne, baba, eş, çocuk) } \\
\text { bilmelerini istemem. }\end{array}$ & .674 & & & \\
\hline $\begin{array}{l}\text { Tatil yaptığım yer, benim için günlük yaşamımda } \\
\text { yapamadıklarımı yaptığım gizli mekânımdır. }\end{array}$ & .663 & & & \\
\hline $\begin{array}{l}\text { Bazı şeylerin günah olduğunu bildiğim halde tatilde } \\
\text { yaptığım olur. }\end{array}$ & .545 & & & \\
\hline Tatilde tanımadığım karşı cinse iltifatlarda bulunurum. & .540 & & & \\
\hline $\begin{array}{l}\text { Tatil dönemlerinde değer ve inançlarım konusunda biraz } \\
\text { daha esnek olabilirim. }\end{array}$ & .462 & & & \\
\hline Boyut 3: Tolerans ve Kuralsızlık & & 5.765 & 45.539 & 0.775 \\
\hline $\begin{array}{l}\text { Tatilde geleceğimi ve geçmişimi düşünmeden anın tadını } \\
\text { çıkarmaya çalışırım. }\end{array}$ & .690 & & & \\
\hline Tatilde olduğum zaman olumsuzlukları görmezden gelirim. & 649 & & & \\
\hline $\begin{array}{l}\text { Tatil dönemlerinde gelecek kaygısı taşımam (meslek, para, } \\
\text { eş, çocuk...) }\end{array}$ & .574 & & & \\
\hline $\begin{array}{l}\text { Tatil atmosferi bazı insanları baştan çıkarabilir (revü kızları, } \\
\text { gece eğlenceleri, animasyon gösterileri gibi). }\end{array}$ & .568 & & & \\
\hline Tatilde karşı cinsle kaçamağa daha 1lımlı yaklaşırım. & .528 & & & \\
\hline $\begin{array}{l}\text { Tatildeki davranışlarım normal davranışlarıma göre daha } \\
\text { kuraldışıdır. }\end{array}$ & .522 & & & \\
\hline Boyut 4: Kimliğinden Sıyrılma & & 5.022 & $\mathbf{5 0 . 5 6 0}$ & 0.699 \\
\hline $\begin{array}{l}\text { Tatilde normalde en yakınlarımın bile bana } \\
\text { yaptıramayacakları şeyleri sırf eğlenmek için yaparım. }\end{array}$ & .806 & & & \\
\hline Tatilde benden beklenmeyecek şeyler yaparım. & .696 & & & \\
\hline Boyut 5:Oyun/Oyuncu Davranışı & & 4.627 & $\mathbf{5 5 . 1 8 7}$ & 0.563 \\
\hline Tatil dönemlerinde kendimi bir oyuncu gibi hissederim. & .749 & & & \\
\hline Tatil dönemlerini bir oyun gibi düşünürüm. & .665 & & & \\
\hline $\begin{array}{l}\text { Tatilde gerçek yaşamımdakine göre daha sahte davranışlar } \\
\text { sergileyebilirim. }\end{array}$ & .529 & & & \\
\hline
\end{tabular}

$\mathrm{Bu}$ davranış türünde birey, yaptığı davranışın uygunluğu/uygunsuzluğu konusunda bir farkındalığa sahip, fakat sadece tatil dönemlerine ilişkin kendisine böyle bir serbestlik verebilmektedir. "Gizlilik” davranışında, etkili olan önemli unsurlardan birisinin tanınmışlık veya tanınmamışlık olduğu söylenilebilir. Tatil dönemlerinde bazı insanlar, 
özellikle yalnız seyahat etmeyi seçerek gittikleri mekânlarda "tanınmamışlık" özelliğinden yararlanarak bu tanınmamışlığın verdiği duygu ile günlük yaşamlarında sergiledikleri kimliklerinden ayrılmaktadır. $\mathrm{Bu}$ davranışa göre turistler, tatil mekânlarında günlük yaşamlarındaki insanlar tarafından bilinmesini istemedikleri şeyleri yapıp, günlük yaşamlarındaki kuralları da bir ölçüde esneterek kendi gizini yaşamaktadır denilebilir.

"Tolerans-Kuralsızlık" davranışında da hazcılık davranışında olduğu gibi insanlar tatilde, geleceği ve geçmişi düşünmeden anın tadını çıkarmaya çalışır. Ancak hazcılık davranışından farklı olarak, kişi anın tadını çıkarmaya çalışırken aynı zamanda olumsuzlukları görmezden gelebilmektedir. Küçük tatsızlıklarla huzurunun kaçmasını istemeyen turist, anlık tatmine odaklandığı için geleceğe ilişkin plan ve programlarını askıya alarak geleceğe ilişkin kaygılanmak istemez. Tatil atmosferinin bazı insanları baştan çıkarabileceği düşüncesi turistlerde egemendir. Bu düşünceye sahip turist, tatilde karşı cinsle kaçamağa daha 1lımlı yaklaşmakta ve tatilde normal davranışlarına göre daha kuraldışı davranışlar sergilemektedir. Bu davranış türünde turist, gününü gün etme mantığıyla kuralları yok sayıp, geleceği ve geçmişi düşünmeden zamanını geçirmektedir.

“Kimliğinden Sıyrılma" davranış türünde birey, gizlilik davranışında görülen kimlik değişiminden biraz daha farklı olarak tatilde, normalde en yakınlarının bile yaptıramayacağı şeyleri sırf eğlenmek için yaparak kendisinden beklenmeyecek davranışları sergiler. Bu davranış türünde, bireyin olduğundan daha farklı davrandığ 1 ya da davranmaya çalıştığı ifade edilebilir. Kimliğinden sıyrılma davranışında, bireyin tatilde farklı bir kimlik sergilediğinin farkında olduğu ve tatil atmosferinin etkisi ile bir ölçüde kimsenin bilmediği yönlerini ortaya çıkararak kendini gerçekleştirdiği ifade edilebilir.

“Oyun-Oyuncu” davranışında, tıpkı her oyunun bir kuralı olduğu gibi tatili de iyi vakit geçirme aracı olarak değerlendiren insanlar konaklama, yeme-içme, eğlence vb. turistik tesislerin kuralları dâhilinde eğlenceli vakit geçirirler. Bu davranış türünde insan, kendini bir oyuncu gibi hisseder, tatil dönemlerini bir oyun gibi düşünür ve tatilde gerçek yaşamındakine göre daha sahte davranışlar sergileyebilir. Fakat bunların hepsi, kişinin bilinçli olarak yaptığ 1 şeylerdir. İnsanlar normalde özendikleri yaşamı, tatillerini geçirmek için seçtikleri bölgede bulunan turizm işletmelerinin sunduğu mekânlarda yaşamaya çalışırlar.

\section{Liminoid Davranış Sergilemede Milliyete Göre Farklılık Analizi}

Yapılan Tek Yönlü Varyans Analizi sonucuna göre tatil dönemlerinde sergilenen liminoid davranışlar ile araştırmaya katılan turistlerin milliyeti arasında hazcılık için [F(4, $460)=34,027, \mathrm{p}=.000]$; gizlilik için $[\mathrm{F}(4,460)=54,497, \mathrm{p}=.000]$; tolerans-kuralsılık için $[\mathrm{F}(4,460)=34,118, \mathrm{p}=.000]$; kimliğinden siyrılma için $[\mathrm{F}(4,460)=5,214, \mathrm{p}=.000]$ ve 
oyun/oyuncu için $[\mathrm{F}(4,460)=16,093, \mathrm{p}=.000]$ olduğundan istatistiksel açıdan anlamlı bir farklılık vardır denilebilir.

Tablo: 2

Liminoid Davranışlar ile Katılımcıların Milliyetinin Tek Yönlü Varyans Analizi ile Karşılaştırılması

\begin{tabular}{|c|c|c|c|c|c|c|}
\hline Liminoid Davranış Tipleri & Milliyet & $\mathbf{F}$ & Ortalama & Std.Sapma & $\mathbf{F}$ & Sig. \\
\hline \multirow{5}{*}{ Hazcılık } & Türk & 93 & 3,0860 & ,90477 & \multirow{5}{*}{34,027} & \multirow{5}{*}{, 000} \\
\hline & Arap & 93 & 3,8065 & ,39722 & & \\
\hline & İngiliz & 94 & 3,8511 & ,43890 & & \\
\hline & Rus & 93 & 3,8495 & ,38859 & & \\
\hline & Alman & 92 & 3,8261 & ,45954 & & \\
\hline \multirow{5}{*}{ Gizlilik } & Türk & 93 & 2,8602 & ,78839 & \multirow{5}{*}{54,497} & \multirow{5}{*}{, 000} \\
\hline & Arap & 93 & 3,8817 & ,38588 & & \\
\hline & İngiliz & 94 & 3,7234 & ,59395 & & \\
\hline & Rus & 93 & 3,9140 & ,43379 & & \\
\hline & Alman & 92 & 3,7174 &, 54118 & & \\
\hline \multirow{5}{*}{ Tolerans-Kuralsızlık } & Türk & 93 & 3,1613 &, 85071 & \multirow{5}{*}{34,118} & \multirow{5}{*}{, 000} \\
\hline & Arap & 93 & 3,8387 &, 42453 & & \\
\hline & İngiliz & 94 & 3,8298 & ,37783 & & \\
\hline & Rus & 93 & 3,9247 & ,30348 & & \\
\hline & Alman & 92 & 3,8370 &, 45155 & & \\
\hline \multirow{5}{*}{ Kimliğinden Siyrılma } & Türk & 93 & 3,2366 & 1,04671 & \multirow{5}{*}{5,214} & \multirow{5}{*}{, 000} \\
\hline & Arap & 93 & 3,7742 & ,69359 & & \\
\hline & İngiliz & 94 & 3,5426 & ,74292 & & \\
\hline & Rus & 93 & 3,6667 & ,90089 & & \\
\hline & Alman & 92 & 3,4783 &, 88303 & & \\
\hline \multirow{5}{*}{ Oyun/Oyuncu } & Türk & 93 & 2,9462 &, 81248 & \multirow{5}{*}{16,093} & \multirow{5}{*}{,000 } \\
\hline & Arap & 93 & 3,6452 &, 65350 & & \\
\hline & İngiliz & 94 & 3,4894 &, 56311 & & \\
\hline & Rus & 93 & 3,3118 & ,60753 & & \\
\hline & Alman & 92 & 3,5435 &, 63615 & & \\
\hline
\end{tabular}

Yapılan Tukey Testi ile istatsitiki açıdan anlamlı farklılığa neden olan gruplar belirlenmiştir. Hazcılık, gizlilik ve tolerans-kursalsızlık liminoid davranış ifadelerine Türk katılımcılar diğer katılımcılara oranla daha düşük düzeyde katılım sergilemektedir. Bu nedenle Türk turistlerin bu tutumu istatistiksel açıdan anlamlı farklılığa neden olmaktadır. Ancak, kimliğinden sıyrılma liminoid davranış ifadelerine Türk katılımcıların dışında Alman katılımcıların da diğer katılımcılardan farklı olarak daha düşük düzeyde onay verdikleri görülmektedir. Bu nedenle, kimliğinden sıyrılma boyutunda anlamlı farklılığa sebep olan grup Türk ve Alman katılımcılardır. Oyun-oyuncu liminoid davranış boyutunda ise, istatistiksel açıdan anlamlı farklılı̆̆a sebep olan Arap ve Alman katılımcılar olmuştur. 
Tatil dönemlerinde bazı insanlar, özellikle yalnız seyahat etmeyi seçerek gittikleri mekânlarda "tanınmamışlık" özelliğinden yararlanarak bu tanınmamışlığın verdiği duygu ile günlük yaşamlarında sergiledikleri kimliklerinden ayrılmaktadır. $\mathrm{Bu}$ açıdan yaklaşıldığında Türk turistlerin liminoid davranış ifadelerine diğer katılımcılara oranla daha az katılım göstermeleri bireylerin yaşamdaki söz konusu esnekliğin de sınırları olduğunu ak1llara getirmektedir. Bu nedenle hem gidilen turizm bölgesi hem de bireyin kendi kültürü tatil anını şekillendirirken, aynı zamanda katıldığı turizm türü de bu anı ve bu ana ilişkin deneyimleri şekillendirecektir.

\section{Liminoid Davranış Sergilemede Tatil Türüne Göre Farklılı Analizi}

Katılımcıların, katıldıkları tatil türü ile liminoid davranış ifadelerine verdikleri yanıtlar arasında istatistiksel açıdan anlamlı bir farklılık olup olmadığı Bağımsız Gruplar Arası T Testi ile analiz edilmiş ve test sonuçları Tablo 3 'te gösterilmiştir.

Tablo: 3

\section{Liminoid Davranıșlar ile Tatil Türünün Bağımsız Örneklem t-Testi ile Analizi}

\begin{tabular}{|c|c|c|c|c|c|c|}
\hline Liminoid Davranış Türleri & Tatil Türü & $\mathbf{F}$ & Ortalama & Std.Sapma & t değeri & Sig. \\
\hline \multirow{2}{*}{ Hazcilik } & Kitle & 247 & 3,8057 & .56551 & \multirow{2}{*}{4,505} & \multirow{2}{*}{,000 } \\
\hline & Kültür & 218 & 3,5459 & 66527 & & \\
\hline \multirow{2}{*}{ Gizlilik } & Kitle & 247 & 3,7166 & 60540 & \multirow{2}{*}{3,250} & \multirow{2}{*}{,001 } \\
\hline & Kültür & 218 & 3,5092 &, 75129 & & \\
\hline \multirow{2}{*}{ Tolerans-Kuralsızlık } & Kitle & 247 & 3,7652 &, 55722 & \multirow{2}{*}{1,826} & \multirow{2}{*}{,069 } \\
\hline & Kültür & 218 & 3,6651 & 61680 & & \\
\hline \multirow{2}{*}{ Kimliğinden Siyrılma } & Kitle & 247 & 3,6883 & 65950 & \multirow{2}{*}{3,837} & \multirow{2}{*}{000} \\
\hline & Kültür & 218 & 3,3716 & 1,04926 & & \\
\hline \multirow{2}{*}{ Oyun/Oyuncu } & Kitle & 247 & 3,3441 & ,71496 & \multirow{2}{*}{$-1,407$} & \multirow{2}{*}{160} \\
\hline & Kültür & 218 & 3,4358 & ,68426 & & \\
\hline
\end{tabular}

Bağımsız gruplar arası $\mathrm{t}$ testi sonucu hazcılık için $[\mathrm{t}(463)=4.551, \mathrm{p}=.000]$; gizlilik için [t $(463)=3.294, p=.001]$ ve kimliğinden siyrılma için [t $(463)=3.943, p=.025$ ] olduğundan katılımcıların hazcılık, gizlilik ve kimliğinden sıyrılma liminoid davranış ifadelerine verdikleri yanıtlar ile tatil türü arasında $p<0,05$ olduğundan istatistiksel açıdan anlamlı farklılık vardır. Tolerans-kuralsızlık için [ $\mathrm{t}(463)=1.837, \mathrm{p}=.067]$ ve oyun/oyuncu için ise [ $\mathrm{t}(463)=-1.411, \mathrm{p}=.159$ ] olduğundan, tolerans-kuralszll1k ve oyun/oyuncu liminoid davranış ifadelerine verilen yanıtlar ile katılımcıların katıldıkları tatil türü arasında istatistiksel açıdan anlamlı bir farklılık bulunmamaktadır.

Gray, 1970 yılında yaptı̆̆ çalışmasında, gezilerin nedenlerini ikiye ayırmış ve bu nedenlerin birincisini güneş isteği, ikincisini ise gezinme isteği şeklinde irdelemiştir. Gray (1970'den akt. Barutçugil, 1989: 34) gezme tutkusunu, bilineni bilinmeyenle değiştirme, 
alışılmış olanı terk etme, farklı mekân ve insanları tanıma gibi isteklerle tanımlarken, güneş tutkusunu, yaşanılan yerde bulunmayanı yaşamak için başka bir yerde daha iyi bir ortamın bulunmasına bağlı olarak oluşan seyahatler şeklinde bir tanımlama yapmıştır. Gray’in de yapmış olduğu bu çözümlemelerdeki gibi tatil için seçilen mekân günlük yaşamda istenilen ve arzu edilen ama ulaşılamayan özellikli bir mekân olmalı ve alışkanlıkların terkedilmesi ve bilinen ile bilinmeyenin yer değiştirmesine zemin hazırlayan bir mekân olmalıdır.

\section{Sonuç}

Tatil dönemlerinde, turistler tarafindan sergilenen liminoid davranışları belirlemeye yönelik olan bu çalışma, öncelikle literatürde eksikliği görülen turist davranışları ve dolayısıyla turist ve tatil psikolojisi konularına önemli ölçüde katkı sağlayacaktır.

"Geçiş ritüellerinde" kullanılan "liminal aşamanın” gönüllü etkinlikler esnasındaki eşiktelik halini tanımlamak için Turner (1979) tarafından önerilen "liminoid" kavramı, bu çalışmada insanların günlük hayatlarına bir süreliğine ara verdiği turistik faaliyetler esnasındaki arada kalmışlık durumunu ifade eden bir kavram olarak ele alınmış ve tatil dönemlerinde insanlarda görülen eğlence ve hazza ilişkin geçici davranış değişikliklerine bir karşılık olarak kullanılmıştır.

Yapılan analizler neticesinde elde edilen bulgulara göre, insanların günlük yaşamlarından kısa bir süreliğine ayrıldığı anda (eşikte) yaşadıkları beş tür liminoid davranış bulunmaktadır. Bu davranışlar, milliyete ve tatil türüne göre değişmektedir. Araştırma sonucunda hazcilık (hedonizm), gizlilik (privacy), tolerans ve kuralsızlık (tolerance and anomaly), kimliğinden sıyrılma (identity detachment) ve oyun/oyuncu (play/player) olmak üzere beş farklı liminoid davranış ortaya çıkmıştır. Her bir davranış türünde, bireylerin günlük yaşamdan daha farklı olarak sergiledikleri ya da sergilediklerini düşündükleri davranışlara yer verilmektedir.

Araştırmada elde edilen verilerin analizi sonucunda ortaya çıkan davranış türleri liminoid davranışlar olarak adlandırılmıştır. Literatürden ve araştırma sonucunda ulaşılan beş liminoid davranış türünden yola çıkılarak "liminoid turist" kapsamında değerlendirilebilecek, hazc1 (hedonist) turist, gizli (anonymous) turist, hoşgörülü (permissive) turist, kimliksiz (faceless) turist ve oyuncu (player) turist olmak üzere beş farklı turist tipi önerilmiştir. Bu turist türleri ve özellikleri şu şekilde özetlenebilir;

Hazcı Turist: Anlık mutluluklara odaklanan hazcı turist, günlük yaşamında gerçekleştiremediği hayallerini ve fantezilerini gerçekleştirmek için turistik mekânları bir araç olarak görmektedir. Hazcı turist, tatilde gününü gün eden, geçici arkadaşlıklar kuran, 
tanımadığı insanlarla vakit geçiren, sınırsızca eğlenen, sorumluluklarından ve kaygılarından uzakta ilkel arzu ve isteklerinin tatminine yönelen turisttir.

Gizli Turist: Gizli turist aile ve yakın arkadaşlarından uzakta, kimsenin kendisini tanımadığı bir ortamda olmanın verdiği bir duyguyla hareket eder. Tatil yaptığı yeri, gözlerden uzakta, kendi gizemini yaşadığ 1 gizli bir mekân olarak algılar. Bu turist, değer ve inançlarını bilinçli olarak terk eder fakat söz konusu terk ediş, geçici bir süreliğine yaşandığı için turisti rahatsız etmez.

Hoşgörülü Turist: Anlık mutluluklara odaklanma, bu turistin de temel karakteri olmakla birlikte hazcı turistten farklı olarak kuralları yoksayar. Geleceğe yönelik plan ve programları askıya alır. Kuralları yoksayan hoşgörülü turist, gününü gün etme mantığıyla hereket ederek tatilin kendisine sağladığı kuralsızlıktan haz alır. Bu turist günlük yaşama ilişkin düzeni bozar hatta olumsuzlukları da görmezlikten gelerek tatilini doyasıya yaşar.

Kimliksiz Turist: Bu turistin en önemli özelliği, planlanmamış bir şekilde sırf eğlenmek için kendisini oyunun akışına kaptırmasıdır. Kimliksiz turist oyunda bir joker gibi oyunun tüm rollerine ayak uydurabilecek bir niteliktedir.

Oyuncu Turist: Oyuncu turist, tatilleri birer oyun olarak görürken, kendisini de bu oyunu oynayan bir oyuncu olarak görmektedir. Bu tür turist, tatilde bir kral ya da kraliçeymiş gibi davranabileceği gibi, kırsal turizm faaliyetlerine katılarak köy yaşamını deneyimleyerek, köylüymüş gibi de davranabilir. Oyuncu turist normalde ait olmadığı bir statüye aitmiş gibi yaparak bu ölçüde hizmet almaktan hoşlanır.

Turist davranışına liminoid eksenli yaklaşan bu çalışma, ulusal ve uluslararası yazının yanı sıra bu alana ilgi duyan veya duyacak akademisyen ve araştırmacılar için bir kaynak teşkil edecektir. Özellikle, turizm ve psikoloji ilişkisine ilgi duyan akademisyenler ve araştırmacılar için çalışmanın yol gösterici olacağı düşünülmektedir. Bu konu üzerinde yapılacak olan farklı araştırmalarla bu tür çalışmaların sayısı ve çeşitliliği artırılabilir. Gelecekte yapılacak olan çalışmalarda farklı turist gruplarına ve farklı turizm türlerine yönelik araştırmalar yapılmasının yararlı olacağı düşünülmektedir.

Turistleri doyum noktasına ulaştıran tatil dönemleri ya da bu çalışmanın önerisiyle liminoid alanlar, gerek turizm işletmecileri gerekse diğer işletmeciler tarafindan turistlerin tatillerine uygun olarak hazırlanmaktadır. Liminoid evrede gerçekleşen eğlence ve hazza yönelik faaliyetlerin turistlerin ruhsal sağlığına katkısı düşünüldüğünde turistler için bu ortamları hazırlayan turizm işletmelerinin varlığının ne kadar önemli olduğu görülmektedir. Başta turizm işletmeleri olmak üzere, tatil bölgesinde faaliyet gösteren tüm 
işletmeler, turist için bir tatil ortamı hazırlayıcısı olarak turistin sergileyeceği davranışlarda moderatör işlevi görmektedir.

Evini ve işini bir süreliğine arkasında bırakarak çeşitli seyahat motivasyonlarıyla yola çıkan turist, bilinmeyene doğru yol alırken yanında bulunacak bir tur rehberinin yanı sıra dilini ve yaşam tarzını bilmemesine rağmen, ayak bastığında dilini bilen bir transfer elemanının varlığı, gidilen yerde yabancı olarak tanımlanan turist için kendisini güvende hissetmesine yardımcı olan unsurlardandır. Bu noktadan hareketle, turizme doğrudan ve dolaylı olarak mal ve hizmet arzında bulunan işletmeler, turisti bulunduğu ortamda güvende hissettirecek uygulamalara daha fazla önem vererek, turist memnuniyetini sağlayacak ve tatmini artıracaktır.

Turistin tatil döneminde sergilediği davranışlar ve tatilden beklentisi gibi konularda önceden fikir sahibi olunması pazarlama karmasından daha etkin bir şekilde yararlanılmasını sağlayacaktır. Bu da daha etkili bir pazarlama ve tanıtım politikasının oluşturularak kıt olan kaynakların etkin kullanılmasını sağlayacaktır.

Turizm destinasyonunda faaliyet gösteren işletmeler, turistin tatil için belirlediği destinasyona ulaştıktan sonra yaşadığı ruhsal hareketlilik sürecinde turistin yanında olan işletmelerdir. Bu noktada önemli olan husus, işletme personeli ve yerel halk için destinasyonun günlük yaşam alanı, turist için ise boş zamanını geçirdiği bir mekân olmasıdır. İşletme personeli, aynı zaman diliminde ve aynı ortamda turistler ile farklı amaçlarla aynı ortamı ve anı paylaştığının bilincinde olmalıdır. Ortam aynı olmasına rağmen, ortamdan beklenen fayda farklıdır. Bir taraf yaşamını idame ettirmeye çalışırken diğer taraf böyle bir kaygıdan uzakta eğlenmeye, dinlenmeye ve rahatlamaya çalışmaktadır.

Turizm işletmelerinde düzenlenecek animasyon ve rekreasyon faaliyetlerine turistin aktif katılımının sağlanması, bulunulan ortama daha kolay ve hızlı bir uyumun yanı sıra ortamdan maksimum hazzın alınmasını da sağlayacaktır. Turistin kendini mutlu hissedeceği bir mekânın görsel ve estetik tasarım sürecinde, turistin beklentileri ve tatilde sergilediği davranışlar hakkında fikir sahibi olunmasının, turist tatmini açısından çok önemli olduğu düşünülmektedir.

$\mathrm{Bu}$ araştırma, bir kişinin turist olarak tatil döneminde günlük yaşamından daha farklı bir kimliğe bürünerek farklı davranışlar sergilediğini vurgulamaktadır. Bu farklı davranışlar, yerel halk ile aynı mekânda gerçekleşmektedir. Bu nedenle, turistlerin sergileyeceği ve muhtemelen bölge halkı tarafından tuhaf, küstah, şımarıklık, saygısızlık, küçümseme, alay edilme hatta bir tür saldırganlık olarak algılanabilecek davranışlara karşı yerel halkın bilinçlendirilmesinin muhtemel yanlış anlaşılmaları ve bu nedenle 
gerçekleştirilecek tacizleri önleyeceği düşünülmektedir. Bu bilinçlendirme faaliyeti, kamu yönetimini temsil eden merkezi ve yerel yönetim birimleri tarafından yapılmalıdır.

Bir turizm destinasyonunun ulusal ve uluslararası tanıtımı genellikle kamu yönetimi tarafından yapılır. Kamu yönetiminin ulusal ve uluslararası düzeyde gerçekleştireceği tanıtım faaliyetlerinde, turistlerin gittikleri destinasyonda ne aradıkları ve hangi motivasyonlarla hareket ettikleri bilinirse, turistlerin ilgisini çekebilecek unsurlara vurgu yapılabilir. Bununla birlikte, bir destinasyonunun tanıtım sürecinde sadece doğal, tarihi ve kültürel kaynaklara odaklanılmaması, destinasyonda bulunan yerel halkın değerlerine de vurgu yapılmasının yararlı olacağı düşünülmektedir.

Merkezi ve yerel yönetimlere bağlı müze, ören yeri ve antik şehir gibi tarihi ve kültürel mirasın bulunduğu mekânlarda, mekâna uygun gösteriler ve canlandırmaların yapılması, destinasyonun çekiciliğinin yanı sıra turistin bu mekânlarda geçirdiği süreçte aldığ 1 hazzı da artıracaktır.

Yerel halka, destinasyonda bulunan sivil toplum kuruluşlarına, mesleki örgütlere ve işletmelere yönelik olarak, turist kimdir? ve turist ne ister? gibi önemli konuların değerlendirildiği çeşitli toplantılar organize edilerek, bölgede turizm faaliyetlerinin sağlıklı bir şekilde gelişmesi sağlanabilir. Özellikle, turizmin henüz gelişmediği fakat geliştirilmesi planlanan bölgelerde yürütülecek tanıtım faaliyetlerinde, turist hakkında yapılacak bilinçlendirme çalışmaları ile turiste karşı herhangi bir tacizi önleyerek hoşgörüyle yaklaşılması sağlanabilir. Bu noktada turist, çalışan ve yerel halkın aynı mekânı paylaşma nedenlerinin farklılıkları üzerinde önemle durulmalıdır.

Turistin, tatilini geçirmek için tercih ettiği destinasyonda bulunan dinlenme park1, ormanlık alan, mesire yeri, çay bahçesi, hayvanat bahçesi ve temalı park gibi genelde kamu idareleri tarafından işletilen veya yürütülen birçok kamusal alana ilişkin düzenlemeler yapılırken, bölgeye gelen turist profilinin de göz önüne alınmasının yararlı olacağı düşünülmektedir.

Çalışmanın ve çalışma kapsamında yapılan araştırma neticesinde elde edilen bulguların genel bir değerlendirmesinin yapıldığı bu sonuç bölümünde; yararlanılan yazın ve elde edilen bulgular ışığında akademisyenler, araştırmacılar, turizme doğrudan veya dolaylı olarak ürün arzında bulunan işletmeler ve bir destinasyonun en önemli paydaşlarından olan kamu yönetimi için öneriler ve alınacak önlemler tartışılmıştır. Bu kapsamda çalışmanın, hem turizmin teorik yönüyle ilgilenen hem de bu teorilerden pratik yararlar sağlamak isteyen taraflar için yararlı bir kaynak olacağı düşünülmektedir. 


\section{Kaynakça}

Altunışık, R. \& R. Coşkun \& S. Bayraktaroğlu \& E. Yıldırım (2012), Sosyal Bilimlerde Araştırma Yöntemleri SPSS Uygulamall, Geliştirilmiş 7. Baskı, Sakarya, Sakarya Yayıncılık.

Bauer, I. (2009), "Relationships between Female Tourists and Male Locals in Cuzco/Peru: Implications for Travel Health Education", Travel Medicine and Infectious Disease, 7, 350-358.

Berdychevsky, L. \& Y. Poria \& N. Uriely (2013), “Sexual Behavior in Women's Tourist Experiences: Motivations, Behaviors, and Meanings", Tourism Management, 35, 144155.

Currie, R.R. (1997), “A Pleasure-Tourism Behaviours Framework”, Annals of Tourism Research, 24(4), 884-897.

Dann, M.S.G. (1977), “Anomie, Ego-Enhancement and Tourism”, Annals of Tourism Research, 4(4), 184-194.

Dann, M.S.G. (1981), “Tourist Motivation an Appraisal”, Annals of Tourism Research, 8(2), 187219.

Egan, C. (2009), "Sexual Behaviour of International Backpackers in the Context of Travel in Australia", (Doctoral Dessertation), University of New South Wales.

Galani-Moutafi, V. (2003), “Tourism Research on Greece a Critical Overview”, Annals of Tourism Research, 31(1), 157-179.

Getz, D. (2008), "Event Tourism: Definition, Evolution, and Research”, Tourism Management, 29, 403-428.

Gottlieb, A. (1982), “Americans' Vacations”, Annals of Tourism Research, 9, 165-187.

Gray, H.P. (1970), International Travel: International Trade, Heath Lexington, Knetucky, USA. akt. İ.S. Barutçugil (1989), Turizm İşletmeciliği, Bursa: Uludağ Üniversitesi Basımevi.

Honko, L. (2006), “Ritüellerin Oluşum Süreci”, (Çev. R. Ersoy), Milli Folklor Dergisi, 18(69), 129140.

Horn By, M. (2010), "Legere Limini: Wanderers vs. Pilgrims in the Liminal”, The Dulia et Latria Journal, 3, 77-116.

Illouz, E. (1997), Consuming the Romantic Utopia-Love and the Cultural Contradictions of Capitalism, California: Universtiy of California Press Berkely and Los Angeles.

Karasar, N. (1995), Bilimsel Araştırma Yöntemi: Kavramlar, İlkeler, Teknikler, Yedinci Basım, Ankara: 3A Araştırma Eğitim, Danışmanlık Ltd. Şti.

Korg, J. (1995), Ritual and Experiment in Modern Poetry, USA: Acme Art, Inc.

Kottak, K.P. (1991), Anthropology The Exploration of Human Diversity, McGraw-Hill, Inc., US.

Kültür Turizm Bakanlığı Yatırım ve İşletmeler Genel Müdürlüğü (2013), <http://www.ktb yatirimisletmeler.gov.tr/TR,9854/sinir-giris-cikis istatistikleri.html>, 10.02.2013.

Lett, J.W.R. (1983), "Ludic and Liminoid Aspects of Charter Yacht Tourism in the Caribbean", Annals of Tourism Research, 10(1), 35-56. 
Pearce, L.P. (2005), Tourist Behaviour, Themes and Conceptual Schemes, Canada: Great Britain by the Cromwell Press.

Ryan, C. (2002), "Stages, Gazes and Constructions of Tourism”, in: C. Ryan (Ed.), The Tourist Experience, 2nd. Edition, Thomson, 1-27.

Selanniemi, T. (2003), "On Holiday in The Liminoid Playground: Place, Time and Self in Tourism", in: G.T. Bauer \& B. McKercher, (Ed.), Sex and Tourism, Journeys of Romance, Love and Lust, The Haworth Hospitality Press, Binghampton, 19-29.

Sekaran, U. (1992), Research Methods for Business: A Skill Building Approach, John Wiley, New York, 253, akt. R. Altunışık \& R. Coşkun \& S. Bayraktaroğlu \& E. Yıldırım (2012), Sosyal Bilimlerde Araştırma Yöntemleri SPSS Uygulamalı, Geliştirilmiş 7. Baskı. Sakarya. Sakarya Yayıncılik.

Shaw, G. \& Williams, M.A. (2004), Tourism and Tourism Spaces, New Delphi: Sage Publications, India, Pvt Ltd.

Sommer, G. (2005), "We Have to Please the Guests Environmental Consequences of the Liminality of Tourism”, 1st International Utech/University of Delaware Joint Conference on Hospitality and Tourism to be Held in Montego bay, Jamaica, October 12-15.

Swarbrooke, J. \& Horner, S. (1999), Consumer Behaviour in Tourism, Butterworth-Heinemann, An imprint of Elsevier Science.

Turner, V. (1974), Dramas, Fields, and Metaphors Symbolic Action in Human Society, New York: Cornell University Press.

Turner, V. (1979), "Frame, Flow and Reflective: Rituel and Drama as Public Liminality", Japaneese Journal of Religious Studies, 6(4): 465-499.

Türkiye İstatistik Kurumu (2013), Turizm Ístatistikleri, <http://www.tuik.gov.tr/PreTablo.do? alt_ id $=51>, 02.03 .2013$.

Varley, J.P. (2011), "Sea Kayakers at the Margins: The Liminoid Character of Contemporary Adventures", Leisure Studies, 30(1), 85-98.

Van Gennep. A. (1909), Les Rites de Passage, (Çev. Monika B. Vizdom \& Gabrielle L. Caffee), Routledge Library Editions-Anthropology and Etnography, 1960.

Wagner, U. (1977), “Out of Time and Place: Mass Tourism and Charter Trips”, Ethnos, 42(1/2), 3852, <http://hotelmule.com/wiki/Liminality>, 20.10.2011.

Williams, S. (1998), Tourism Geograpy, New York: Routledge is an imprint of the Taylor \& Francis Group. 
Aktaş Polat, S. (2015), "Turistlerin Tatil Dönemlerinde Sergiledikleri Liminoid Davranıșlar”, Sosyoekonomi, Vol. 23(26), 99-117. 